\title{
愛増を表わす旧約へブライ語動詞語彙の構造
}

松田伊作

1.1. 語裹とは同一言語に括ける単語の集合であり, 従って語彙構造 とはこの集合の成分たる各単語の意味の相互関係のことである。この小 論では旧約聖書のへブライ語で,「愛する」「憎む」という類いの, 他者 に対する人の心のはたらき—これを対人精神活動と呼ぶ——を表わす 動詞を対象として，その語彙構造の一面を解明しょうとするものである。 ところで，旧約へブライ語にはそのような愛憎を表わす動詞が，西欧語 や日本語にくらべて極めて多い。例兄ば「愛する」と訳すことのできる 動詞には, 'hb, ḥpș, ḥšq, ḥbb があり,「嫌う」と訳されるものに至 っては, śn', m’s, tb(pi), gel, qwș, šqș, nq', qwț(ni), zhm の多 きに上る。だからある言語の語彙をこのように訳語に即して一一すなお ち他国語の観点に立って一一見るとき，その言語にはいく組もの’同義 語”が存在することになってし亦う。しかし一般に，音形（旧約へブラ イ語のような文献言語に扔いては書形というべきか）の異なる二つ， ま たはそれ以上の単語はその意義素も互いに異なるはずだ，という原則を われわれはたて, 語菓構造はその言語自体に即して考察されければなら ない, と考光る。

先の拙論に括いてわれわれが, 対人精神活動という意味分野に属する旧 約へブライ語動詞のうち，比較的多くのヴァラエティに富んだ用例をも つ七つの動詞, 'hb, śn', rșh, hipṣ, rhmm(pi), ḥnn, ḥml Kついて, それぞれの意義素を仮定したときも，上記のような原則ないし考方方に よったのであった。その際結諭に到達するまでに抗こなった分析の手順 を, 本論では語彙構造の解明とい5角度からも5一度体系的に見直しつ 
オリエントXVII-1 (1974)

つ整理してみようと思うのである。

1.2. 意義特徵 例光ば日本語のアニ（见）とい5単語の意義素は才 トウトのそれとく年上／年下》といら特徴のみによって区別され，アネ の意義素とは《男／女》といら特徵のみによって区別される。そして 《年上》といら特徵はアニとアネに共通であり，《男》といら特徵はア ニとオトウトに共通である。こうして，アニ・オトウト・アネ・イモウ トという四つの単語から成る語轾の構造は上記の二対の特徵の組合せに よって記述することがでさる。さらにチチ（父）といら単語をもってく ると，上の四つの単語の意義素には共通で，チチのそれにないほきょう だい》という特徵が浮び出る。このよ5にいくつかの単語には共通で, 他の単語にはない意味上の特徵，いいかえればそれによって一組の語が それ以外の単語と意味上識別されろ特徵を，意義特徵と呼ぶことにする。 ただし所与の意義特徵が普遍的にどの言語にも設定できるとは限らない。 例えばせきょらだい》という意味分野に属する英語の単語には brother と sisterがあるのみで，ここではく年上／年下》という意義特徴は立て られない。言語ごとの語彙構造の相異は，だから，意義特徵の種類と組 合せ力の相異に帰することができる。さて実際の言語使用に当って例え ば，ある人物について私が「彼八私ノ兄ダ」と言えるためには，その人 物と私との関係に打いて，アニという単語の使用を可能にする条件が存 在しなければならない。だから意義特徵は所与の単語の使用を可能にす る言語的ないし非言語的条件ともいうことができる。もっともわれわれ が問題にしている精神活動という意味分野は，親族名称のような意味分 野とはいくつかの点で性質を異にする。第一に, 後者に属する単語は, 各言語ごとに外延の明膫な，閉じた体系をなしているが，前者の語彙は それ以外の意味分野に属する単語との境界が必ずしも明白でない。第二 に，これと関連して，後者に属する単語はそれぞれの意味領域が互いに はっきり分れて招り，乙かもそれらだけでこの意味分野を余す所なく埋 めているが，前者ではそうではない。その結果，第三に，後者において は同一意味分野の内部では，必要かつ充分な意義特徵を挙げることがで 
愛憎を表わす旧約へブライ語動詞語彙の構造（松田）

きるのに対し，前者では必ずしもそうではない。このような意味分野の 性質上の相異は，実際の言語使用に際して，わ孙机ある人物が自分 と親族関係にあるか否か，あるとすればいかなる間柄であるか，言葉に よってはっきり述べることができるはずであるのに対し，ある人物に対 する自分の感情を完全に言葉で表現することは困難だ，といらわれわれ の経験事実にも対応する。

1.3. 方法 すでに先の拙論で述べたよ5に，われわれの対象言語は 旧約聖書という一文献に，原則上それに付加えることもとれから取去る ことも許されないものとして，提示されたものである以上，問題の単語 の意義特徴を抽象するための唯一の手がかりはこの文献だけである。文 献に即して言語的ないし非言語的条件を取出すにはどのような方法が可 能であろうか。言語的条件に該当する意義特徵は, 服部四郎氏の提唱さ れた ‘語義的同位置の作業原則”拈よび“語義的呼応の作業原則”にも とづいて引出すことができる。非言語的条件に該当する意義特徴は, 音 声言語の場合だと，発話の場面の観察や発話者の内省に関する報告にも とづいて，取出すことができるわけであるが，われわれの場合には，先 の拙論で説明した“意味場面”の分析によって，不十分ながらある程度 は，引出すことができる。やや具体的にいえば，問題の動作の主体や客 体についての情報, その動作がなされる前後にどのような出来事があっ たか，などを対象の個所の記述から知ることができるし，またその情報 を文献学的・神学的研究の成果を利用して, 精密化することもできる。

ここで序でながら単語の意味に対する他の接近方法に触れて和きたい。 従来言語学的ないし意味論的な万法とされてきたのはほとんどひたすら 歴史的・比較的方法である。むしろ語源論的 (etymological) な方法と いった方がよいかもしれない。すなわち，所与の単語が，近隣の言語の いかなる単語と同系であるか，あるいはいかなる言語から借用されたか を‘発見’して，その単語の意味をもって問題の単語の意味を推定する というやり方である。しかしこのような方法は問題を他の言語にすりか えたにすぎない。元の意味とか真の意味とかいったところで，そ机は別 
の場所か別の時代におおる意味にすぎないわけだから，それはそれでや はり共時的方法で解明され記述されねばならない。問題は, その単語に よって同時代の人々方何を表象したかといらことである。勿論, 用例が 少なく文脈に乏しい単語については，比較言語学の成果が功を奏するこ ともある。例えば上に挙げた ḥbb のごときは旧約聖書に一例しか出な

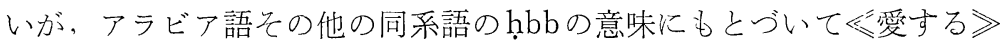
という意味を推定し得るものの，それ以上の細かいこと，例光ば’hb と 区別されるための意義特徵までは分らない。

さてわれわれは問題の語裹の意義特徵を，(1)主体（2)客体（3)主体と 客体との関係 (4)客体に括ける前提条件 (5)随伴的事象という五つの観 点から，上記のような方法で分析しつつ各語の意味の相異をできるだけ 明らかにしてゆきたい。

2.1.1. 所与の七動詞について, その主体と客体を語義的意義特徴に 従って，人・神・その他と分けてそれぞれの百分比を示すと次のょう になる。

\begin{tabular}{|c|c|c|c|c|c|c|c|c|}
\hline 主 体 & 客 体 & 'hb & śn' & ḥpṣ & rșh & ḥnn & rḥm & ḥml \\
\hline 人 & 人 & 39 & 63 & 8 & 20 & 25 & 19 & 37 \\
\hline 11 & 神 & 8 & 4 & 0 & 0 & 0 & 0 & 0 \\
\hline 11 & その他 & 36 & 23 & 39 & 12 & 0 & 0 & 20 \\
\hline 神 & 人 & 12 & 5 & 14 & 32 & 73 & 81 & 35 \\
\hline 11 & その他 & 5 & 5 & 39 & 36 & 2 & 0 & 8 \\
\hline
\end{tabular}

2.1.2. 主体上の表によれば問題の動詞はみな，人（または神）を 表わす（人称接辞をも含めた）形式を主語としてとろからこれらの動 詞が共有する意義特徵として人間または神を主体とする活動を挙げるこ とができる。そして 'hb，sn'は人を主体とする例が压倒的に多いが， ḥpṣ, ḥml では人之神之ほぼ同率, rṣh では神の方がやや多く, ḥnn, 


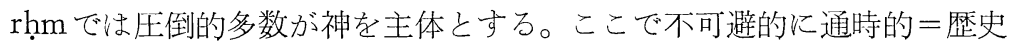
的考察に入ることになるが，全般的にみて，神（jhwh または 'lhjm) を主体とする例は人を主体とする用法よりも抏くれて始まっている。つ まり世俗的な用法に次第に神学的用法が加わってくる。このことと対応 して, hnnn, rḥm の用例は, 人を主体とするものも含めて, 比較的後期 のものが多い。創世記で hann が出る三つの個所 (33:5,11 $43: 29)$ はいずれも「ェローヒームが hุnnする」いう定型的表現であるのは注 (9) 意を要しよう。

'hb が神のこととして言われる最も古い個所の一つにホセア書 $3: 1$ がある。ここで, 乾葡萄の菓子（=カナン文化）を愛するイスラェルの 民に対するヤ八ウェの愛の行為を, 夫以外の男を愛する女に対するホセ アの愛によって象徴させているわけであるが，このことは見方を逆にす れば，神の民に対する愛を男の女に対する愛からの類比として考えてい ることである。これに対し比較的後期の個所では，例えば「ヤ八ウェは 義しい者を愛する」（詩 $146: 8$ ）のように神学的色彩が濃く定型化の傾 向がうかがわれる。しかしながら全体として旧約聖書の言語では，世俗 的・神学的というような截然たる意義特徵を立てることは危険で, この 点たとえばコーランのように初めから宗教的目的の下に書か礼た文書と は異なる、ということができよう。

2.1.3. 客体 上掲の表によって見ると, 'hb と sn'とはすべての客 体をとり得るのに対し, hpș, rṣh, hann, rḥm, haml は人を主体としつ つ神を対象とすることがなく，その中でもさらに ḥnn と rḥmは人間 以外のものを対象とすることが皆無に近いという点で, 他と区別される。 ḥml はこの表からだけ見ると, hapș, rṣh と同じ分布を示すかのようで あるが，実際は「その他」の対象の内訳が異なるのである。すなわち， hml は, hpṣ や rṣh のよ5に, 「神の道を知ること」(イザ58: 2 ヨブ $21: 14$ )のような不定詞句や「人の道」（筬16:7 23:26）のよ5な名 詞句によって表現された抽象的な事柄を対象としてとることがなく， 主として「家畜」(サム上 $15 ： 9)$ とか，「弓つわ」(イザ30：14），「矢」 
オリエントXVII—1 (1974)

（エレ50：14）のような具象物を対象とする。以上のように，大をかな特 徵にもとづく客体の分類によって, まず 'hb と śn', hạs と rṣh, ḥnn 之 $\mathrm{rhm}$ ，および hml がそれぞれ別個の意味分野を形成することが分っ た。そこでつぎに，この各分野ごとに、「その他」の客体の内訳を対比 検討する。まず 'hb は，「食物」(創27 : 4,9,14 ホセ3: 1 筬21：17） や「金銭」(伝5：9），「眠り」(イザ56：10 筬20：13）のよ5な具象度 の高い対象をも取る点で śn’と異なる。闭者に共通の対象は「善」「悪」 「知恵」「義」のような道德基準である。

hpṣ と rṣh とに共通の対象となり得るのは「犠牲」「捧げ物」のたぐ いだけである。この二動詞のうち hps だ壮が客体として取ろのは「恵 み, 招きて, 義」等 (ホセ6:6 エレ9:23 詩 $35: 26,27 \quad 112: 1119$ : 35),「ヤ八ウェの言葉」(エレ6:10)。「悪人がその道から立帰ること」 (エゼ18:23 33:11), 「神に近いこと」(イザ58:2),「神の道を知る こと」(イザ58:2 ヨブ21：14)，「祝福」(詩109:17)，「栄誉を与兄る こと」(エス $6: 6$ 等) などであるのに対し，rṣh だけが客体として取る のは「人の手の業」(申33:11), 「人の仕事」(伝 $9: 7$ ), 「人の道」(筬 $16: 723: 26)$, 「日」( それぞれの客体群に共通の意義特徴として, hpṣ の客体はプラスの価值 を付与された倫理的概念であるということ, rșh のそれはそれ自身価值 に関しては neutral で，具象性の高い事柄である，ということがいえよ 万。

2.1.4. 主体と客体との関係 問題となるの依，人または神を客体と する場合の，両者の関係である。女の男に対することとしては 'hb（サ ム上 $18: 20,28$ エゼ $16: 37$ 雅 $1: 3,4$ ホセ3:1) と触（エゼ16:37 $23: 28$ ) だけ，人の神に対する態度としても 'hb（申 $6: 5 \quad 11: 1 \quad 13$ $: 4$ 王上 $3: 3$ 詩 $31: 24$ 等) と觔 (分詞形で, 出 $20: 5$ 申5:9 7 : 10 代下19：2）だけが用例を有し，他の動詞は用いられていない。’hb はさらに奴隷の主人に対する（出21：5 申15：16）, 嫁のしうとめに対 する（ルッ $4: 15 ）$ 態度としても出てくる。以上の考察にもとづき, 
《身分の高い者の低い者比刘す万行為》という意義特徵を, hpṣ, rṣh, ḥnn, rhm, hml 飞捻いて認めることができる。

2.2.1. 客体における前提条件 所与の動詞はすべて「人」を客体之 して取ろことができるから，客体の存在が主体の側の行為の前提で山る ことはいうまでもない。ここでは客体たる人物の属性や態度について， その意義特徵を考察する。

2.2.2. 'hb 客体について何らかの説明的記述がある個所を拾って ゆくと，まず男女間の場合，イサクが’hbした（創24：67）リベカにつ いて，ずっと前の方にではあるが「この娘は大へん見目よく，まだ男に 知られぬ処女であった」（創24:16）と報ぜられており，ラケルは「姿 も見目も美しかった」（創29：17）といわれ，アムノンの相手について は「ダビデの子アブサロムには名をタマルという美しい妹があった」 （サム下 $13: 1$ ），エステルについても「この乙女は姿美しく，見目よか った」（エス2：7） と記されている。その他の場合は対象たる女性の存 在がいわれるのみである。しかし問題の女性について説明的記述がある 場合はこのように一樣に「美しい」(jph) とか「見目よい」(țbt-mr'h) と形容されていることは注目に值しょう。つぎに親子の間のこととして は，イサクが鳥獣の肉を好んだので, 猟師となったェサウを’hbした（創

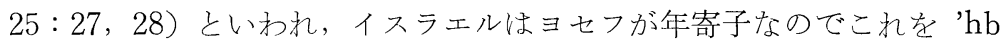
した（創37：3）とされる。ヤ八ウェが主体である例では「ヤ八ウェは 義しい者を'hb」(詩146:8), 「正義を求める者はヤ八ウェに 'hbされ る」(筬15：9）などがある。以上の考察で一応明らかなように, 'hb は 客体の側の行為や態度を前提とはしないが，主体にとって好ましい属性 を備えていることを前提とする，と言うことが許されよう。

2.2.3. śn’ ヤコブに sn'されたレアは「目がどんより（rkkwt）」

（創29：17）と書かれているが，客体に括ける属性の記述はこれ以外の 例が見出せない。アムノンの不祥事 (サム下13）についてもタマルをśn' するに至った動機は一切記されず，原因はアムノン自身にあることを推 察させるのみである。しかし次のような例の考察と, 後に見る'hbとの 
オリエントXVII-1 (1974)

意義関係に基づいて，客体に呿ける主体にとって好ましくない属性ない し行為，という前提条件が推定される。ヨセフが夢を見てとれを兄剃た ちに話したので彼らはますます彼を sn'した（創37：5，8）。アムノン が自分の妹を辱かしめたので，アブサロムは彼を śn'（サム下 $13: 22$ )。 イスラェルの王はミカヤが悪い事だけを預言するので彼を sn'（王上22 ：8）。「門を吒いて戒しめる者を彼らはśn'」（アモ5：10）。「暴行を好先 者をヤ八ウェは的」」(詩11:5), 等。

2.2.4.rșh「わが聖なる山でイスラェルの全家は挙って私に仕光 るであろう。そこで私は彼らを $\operatorname{rsph} \cdots$ (エゼ20：40）の上うに，客体が 主体の気に入ることをして積極的に主体に働らきかけることが rșh の前 提となる。その他, ヨブ33：26, サム下 $24: 18$-23, 詩 $147: 11$ 参照。 「山に上って木を伐り出し，神殿を建てよ。そうすれば私はそれを $\mathrm{r}$ 穴 ‥」」(ハガ1：8）のように前提条件たる行為が主体から客体に向って命 令されること我ある。2.1.3で「人の手の業」「人の仕事」「人の道」を 目的語とする例があることを見たのであるが，これらの名詞句の基底に は「人が女る業をなす」という意味構造が横たわっていると考えること ができるのである。

2.2.5. hps 総じて客体の属性や行為の記述を欠いている。ただこ れも上で (2.1.3.) 見た，「恵み」「拈きて」「義」「ヤ八ウェの言葉」 「悪人がその道から立㷌ること」「神に近いこと」「祝福」のような名詞 句を対象として取ることから, 'hb と同じく主体にとって好ましい性質 を備觉ていることが，客体の前提条件になっているといえよう。上のよ らな名詞句は, rṣh が支配する名詞句と異なって，主体を意識した業で はなく，そのこと自体が善であるような状態を意味している。「悪人が その道から立帰ること」を hps すするのであって,「悪人を, その道から 立帰るから」hpṣするのではない。

2.2.6. rḥm「君がヤ八ウェに立帰ってその声を聞くとき，君の神

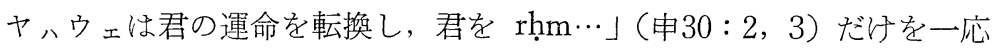
の例外として，rhm する主体に対する客体の側の条件は明示されてい 


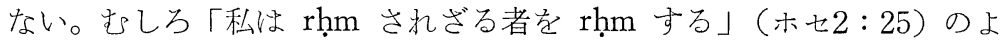
らに近説的に，rhm される資格を欠くことが $\mathrm{rhm}$ される条件である とさえいわ机る。この事実は $\mathrm{rḥm}$ が親の子に対する態度として用いら れる（イザ13:18 49:15 詩103:13）ことによって裏書される。親 の子に対する感情は生得的なもので, 子の側の属性や行為によって惹き 起されるのではない。このように見ると, 最初にあげた個所の「ヤ八ウ ェに立帰る」ということは，rhmとの関連では，本来の養父子・契約関 係に戻るといらことで, ヤ八ェに対する「業」ではない。

2.2.7. ḥnn ダビデはその子が病んだとき断食して引籠った。子供

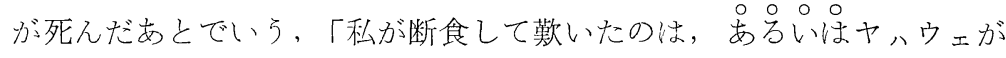
私を ḥnn し，子供は生きるかもしれないと思ったからだ」（サム下12 : 22)。「悪を憎夕, 善を愛し, 門で公義を立てよ。和关らうは。軍の神 ヤ八ウェ，ヨセフの残りを hnn し給うであろう」(アモ5：15)。「私忙 誠実に歩む，私を贔い，私を h.nn し給克」（詩26:11）のよ5な例で は，たしかに客体の行為が前提をなし，また「私を hnn し給光，私は 弱り衰えています」（詩6:2，3）のよ5な例では, 客体の状態が前提で あるかのように見光る。乙か乙既に見た'hb や rṣh との大きな相異点 は, 客体の側の前提条件（と見られるもの）が明示されている個所で, 'hb p rṣh は完了形をとったり一人称で出たりすることが多いのに対 し， hnn は例外なしに未完了形なたは命令形をとり，そして一人称で

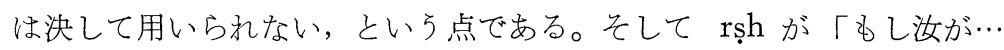
するならば，私は（必らず）汝を rṣhする」という型をとるのに対し，

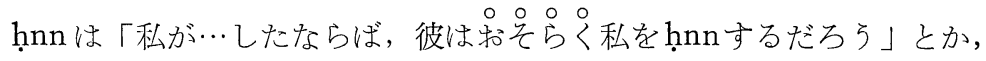
「私は…状態にあるから，ぞらか私をḥnnして下さい」といら型をと る。 $\mathrm{rhm}$ と比べると, $\operatorname{rhmm}$ は人称で出ることも多く, そして客体の側 の条件を問わないことは上に見たと特りである。そして hnn と対語をな すこともあって，共に「粼む」と訳される。このように見てくると， 同じ「憐れみ」という行動を主体の側から把えるときにはrhmといわれ， 客体の側から把握（むしろ希求）するとき hnnといわれる，之結論する 
オリエントXVII-1 (1974)

ことができよう。客体の側から希求することだから不確かなので「扔そ らく」といわれたり，命令形の形をとったり寸るのである。だから最初 から問題にしている客体の側の行為ないし状態は, この ḥnnといら動詞 の場合, 少なくとも出来事（二起ったこと）の前提条件と見ることはで きない。むしろ, 詩篇に頻出する hnnj「私を憐れみ給光」(4:2 6:2,

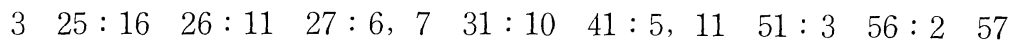
:2 $86: 16 \quad 119: 58,132 \quad 123: 3$ 等) という叫びの場合は, この叫 び自体と叫びを余義なくさせている状沉とのすべてが，叫びの対象とな

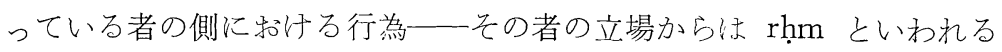
べき行為——の前提だということができよう。

2.2.8. hml 客体に括ける条件は全く明示されていない。

2.3.1. 随伴的事象 前節で見た前提条件の場合之は反対に，rșh 以 外の動詞では, 問題の精神活動に伴なって何らかの具体的な出来事がも たらされたことがしばしば明示されている。そのような随伴事象ないし 結果という観点から見ると, 各動詞について如何なる意義特徵が浮び出 るか，これはすでに先の拙論に沶いて述べたことでもあるので，ここで は簡単にまとめるにとどめて扔く。

2.3.2. 'hb 主体が人間の場合は, 客体に固着ないし結合する（創34 $: 2,3$ 王上 $11: 1-2$ 申 $11: 22 \quad 30: 20$ 創 $34: 8$ 申 $10: 15$ サム 上18：1)。とりわ㪴男女間の場合には, 結婚ないしそれ以外の性関係 （創24:67 29:18 申21:15 士14:16 16:4, 15 サム上 $1: 518$ : 20 サム下 13 王上 $11: 1$-3 ホセ3:1 エス $2: 17$ 伝 $9: 9$ 代下 $11: 21$ )。主体が神の場合は「選び」（申 $4: 37 \quad 10: 15$ 詩 $47: 5 \quad 78$ : 68 申7 : 13，14 イザ $43: 4$ ホセ $11: 1$ マラ $1: 2$ )。

2.3.3. śn’ 主体が客体を「追放」する（サム下 $13: 15$ 一18 創 26 ： $27 \pm 11: 7$ ホセ9:15), 「殺す」ないし「減す」（創 $37: 20$ 詩 $5: 6$ 一 $50: 17$ サム下 $13: 23$-29 アモ6:8)。

2.3.4. ḥps 客体にとって望ましいことが主体によってもたらされ る。例光ば，シェバの女王はソロモン王に「ヤ八ウェがあなたを hps し 


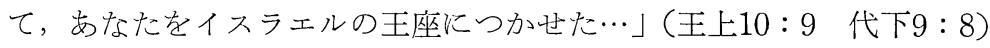
といい，詩人は「私の敵が私に災いを及ぼし得ないことによって，あな たが私を hp̣ ことを私は知る」(詩41：12）と歌う。その他, 民14:8, サム下 $22: 20$, 詩 $18: 20,22: 9$ ，イザ $62: 4$, サム下 $15: 26$ 。

2.3.5. rḥm 神がイスラェルの民を再び選ぶ（申13：18 イザ14： $154: 7$-10 60:10 エレ12:15 30:18 ゼカ10:6), 「運命を転 換する」(申30:2，3 エレ33:26 エゼ39:25)。

2.3.6. ḥnn 客体を穹状から救い出す。人を主体とする場合には, 「義人は hann し, 与光る (分詞形)」(詩37:21),「ḥnnして貸し与兄 る」（詩37：26 112：5）等のよ5に貧者を助けることとパラレルに出 てくる。従って否定辞を伴ならと「彼の全財産を債権者に取らせ，彼の 所得を他の人たちに奪わせて, 彼を hnn する者はなくなり…（詩109 ：12）とか，さらには「地の果から一つの民が攻めて来て…幼い者を ḥnn せず…君を滅ぼしつくす」(申28：50)，「…君は彼らを滅ぼしつく さ敞ばならない....彼らを hnn してはならない」（申7:2）といらことに なる。前節 (2.2.7) に挙げた詩篇の「我をḥnn し給光」といら神に対 する呼びかけが，自分の救いを求める叫びであることは文脈上明らかで ある。

2.3.7. ḥml 客体を殺したり, こわしたりしないでとっておく（サ ム上 $15: 9$ サム下 $21: 7)$ 。従って否定辞を伴ならときは, 客体を殺し たりこわしたり，失なったりするという結果になる(申13:9，10 サ ム上 $15: 3$ イザ $9: 18$ エレ $13: 14 \quad 21: 7 \quad 51: 3$ エゼ $9: 5$ ハバ 1 $: 17$ ゼカ $11: 5,6$ ヨブ $16: 13 \quad 27: 22$ 哀 $2: 2,17,21 \quad 3: 43$ 代 下36:17 イザ30:14 エレ50:14 ヨブ20:13)。

3. 'hb と śn' この二動詞の意義関係を, 先の拙論では一般の見解 と同じく ‘反義的”としたが，本論ではその見解を訂正して両者は“相 補的' (complementary) 意義関係にあることを実証したい。一対の単 語 $\mathrm{x}, \mathrm{y}$ が，これらと呼応する意義特徴を有する単語 $\mathrm{A}$ に関して「 $\mathrm{x}$ な

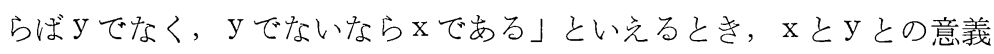


オリエントXVIIー1 (1974)

関係は相補的だ，という。従ってx，yが動詞ならば，Aがこれらと主 語（又は目的語との他）の資格で統合して，例えば「Aがxする」とい えるときは必ず「Aがyしない」ということができ「Aがyしない」 とい光るときは必ず「Aがxする」とい光なけ机ばならない。まず $h b$ と śn’とがこの二つだけで相補概念を表わし得るためには，「SがOを 'hb しない」といわれるときに「SがOを śn'する」とはいわれず「S がOをVする」といい,得るよらな $\mathrm{V}\left(\mathrm{V} \neq \mathrm{J}^{\prime h b}, \mathrm{sn}^{\prime}\right)$ が存在する，とい う事実が成立してはならない。所与の資料でこのような動詞は見出せな いから，'hbと śn'とは少なくとも対立 (opposite) 概念を裴わずとい うことがでさる。実際，アムノンと義妹タマルとの関係に見られろよう に，この両語は全く同一の文脈に現れることがでさるのである。さて士 師記14：16でサムソンの妻がサムソンに言った言葉 rq-śn'tnj wl' 'hbtnj くあなた性を憎をだけで私を愛していない》で sn'と'hb の否定と が並置されて出てくろ。先の拙論で両語の関係を ‘相補的”之認め得な かったのは, この文が上掲の論理式の一方しか満足させていないと解し たからであったが，ヘブライ語の接続詞 $\mathrm{w}$ は形式論理学的な「ゆえに」 という意味を必ずしも表わさず，ここではむしろ，śn’といことを， 'hb の否定によって言換光つつ, 強調している，と見るべきであって， 表現者の心中に「埙'だから 'hb でない，'hb でないなら śn'だ」とい ら観念があったことは十分らかがわれるのではなかららか。「私ニヤ、

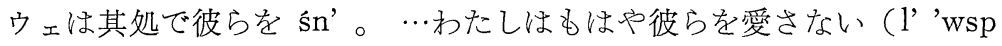
'hbtm)」(ホセ9：15）についても同様のことが言光る。この他「偽り の誓いを'hb するな, これらすべてを私は sn'」(ゼカ8:17) では主体 を異にするけれぞもやはり śn'が 'hb の否定で言換光られている。次 の例では逆に sn' の否定が 'hb で言換觉られていると見ることができ よう。「心の中で君の兄弟を śn'するな…自分のように君の隣人を'hb せよ」(レビ19:17-18)。

'hb の否定は, この動詞の用例約140の中, śn' と並置された上掲の 3 例を含めて, わずか 5 例, śn'の否定に至っては, 約85の用例中, 上出 


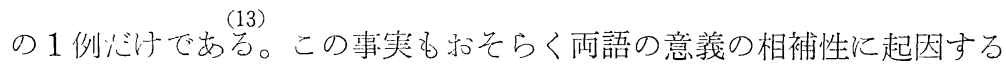

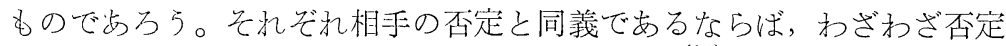
辞のついた圥長な形式を使ら必要はないわけである。

これまでの推論は，'hb と sn'とが対語として現れる，上記以外の個 所の分析によって裏付けされるであろう。まず主体が同一者の場合，客 体は対立（ないし相補）概念を表わす。「われヤ八ウェは公義を'hb，不 法な強奪を śn’」(イザ61：8)，「悪を śn’し，善学'hb せよ」(アモ5：

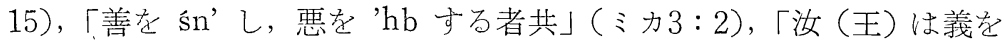
'hb, 覀定 sn'」(詩45:8), 「私（詩人）は二心の者を śn', 汝の律法炎 'hb」(詩119: 113)，「私は汝の命令を 'hb，‥ずへての偽りの道を śn'」 (詩119: 127-128), 「私は偽りを śn'‥, 汝の定めを'hb」（詩119： 163)。

客体が同一者の場合は主体が対立させられる。「私を和する父たらの 然を艺の子らに罰して三，四代に及注し，私を’hbする‥者のためには 恵㕛を施して千代に及ぼす」（出20：5一-6），「湖る者を責めるな，彼は 君を śn'，知恵ある者を責めよ，彼は君を'hbしよう」（箴9：8），「自 分の答を惜しむ者は息子を sn' 寸る者, 息子を'hb する者はつとめて これを懲らしめる」(箴13:24)。

伝道の書 $3: 2-8$ の教訓詩では「生れる一死ぬ, 殺す一疹す, 泣く一 笑う, さがす一なくす, 黙る一語る」等々の対語と並んで 'hb一战'が 挙げられている。一時には一事しかでさない，という教訓をこの詩は語 っているとするならば，ヤコブがラケルを愛してレアを憎み（創29）, ヤハウェがヤコブを愛してェサウを憎さ（マラ1：2-3）とか，「男に二 人の妻があって，その一人懓され ('hwbh)，一人憎まれ('snw'h) ていて․」(申21：15）とかいわれていることから，ひとは一時に一人 のものしか愛することがでさない，そして愛していないことは憎んでい ることだ，という思想を読取ることもできよう。 
オリエントXVII-1 (1974)

註

1）「意義素」「意義特徵」といら術語は服部四郎氏の定義に従う（服部四郎 「意味」,『岩波講座 哲学11 言語』岩波書店, 1968等を参照)。簡単に説 明すると単語の意味的側面を意義素という。「単語」という非連続的 (discrete）な単位は抽象的な心的実在であるから, 単語の意義である意議素も抽象 的なものであって，いわばわれわれの脳裏に存在するとしか言えないもので ある。従ってわれわれは意義素を「仮定」するといら。

2）松田伊作「旧約ヘブライ語の対人精神活動動詞の意味」、『文学研究』第70 輯, 九州大学文学部, 1973，63-80頁。

3）語形は便宜上子音文字のみで示しているが，問題にしているのは語根の意 義ではなく，基本形（qal）——だし rḥm だけは piel 形——の各動詞の すべての変化形式——なおち「完了形」「未完了形」「命令形」「不定詞」 「分詞」一に共通の意義である。語根の意義を扱うならば，動詞だけでな く，それから派生した名詞等の意義素をも考察しなければならないであろら。

4) 'hb 《相手を望ましいものと認め，これと精神的にも肉体的にも結合する ことを強く欲する》

Śn’《相手をしりぞけ，できれば消隇させるこを強く欲する》

$\mathrm{rṣh} \ll$ 気に入ったものとして受入れてやる》

h.ps 《その存在を喜ぶ》

$\mathrm{rhm}$ 《自分の子として認知し, 大事にしようと思ら》

ḥnn 《願いを叶觉てやりたいと思ら》

hml 殺したり，失なったりしたくないと思う》

5) Leisi, E.: Der Wortinhalt. 2. Aufl. Heidelberg: Quelle \& Meyer, 1961, p.19 参照。

6）服部四郎：上掲論文，324頁。

7) Ch. Rabin は他の古典語と比べて聖書へブライ語の意味研究がおくれてい ることの理由として ‘神学的意味”に対する先入主があることと並んで, etymology の過大評価を挙げている (Rabin, Ch. : “Hebrew”, Current Trends in Linguistics, 6. Linguistics in South West Asia and North Africa, the Hague, Mouton, 1971, p.312)。

8) Barr, J.: The Semantics of Biblical Language, Oxford, 1971, p.107 以下 参照。なお1970年以来ドイッで並行して刊行されつつある二つの「旧約神学 辞典」(Theologisches Wörterbuch zum Alten Testament. W. Kohlhammer; Jenni-Westermann 編: Theologisches Handwörterbuch zum Alten Testament. Chr. Kaiser) は語源考察だけでなく, 語彙論的意味研究の成果をも提 供している。

9）ただし Gunkel 以来註解者の多くは33:9，11をE資料とするのに刘し, 43:29 は J 資料としている。 
10）コーランでは例光ば「愛する」と訳される一番普通の動詞 'ahabba は wallāhu yuhibbu-1-muhsiniyna 《アッラーは善をなす人々を愛し給ら》(3: 128，141 5:94）のように“神学的’な用法が大部分で，男女間のこととし ては出てこない。

11）もらろん記述がないからといって，これらの動詞の使用が客体の条件の如 何にかかわらず許された，と結論することはできない。多くの場合，問題の 行動自身の属性が客体をも規定するため，わざわざ客体を明示的に容飾する 必要はないのである。しかしわれわれは明示的な記述のみを手がかりとする のであるから，書かれていないことについては結論を差控えざるを得ない。

12）拙論ですでに引用したテクストは個所を挙げるに止め, 新らしい所論につ いてはテクストを引用した。

13）名詞化した分詞形 'ōhēb 《友》, sōone 《敵》を除く。

14）これらの例では，'hb と śn'とが相補概念を表わすことを利用して，同一 語を繰返さないという文体論的効果をねらって，あえて否定辞を伴なら形式 を用いたのであろう。

15) Galling, K. : "Das Rätsel der Zeit im Urteil Kohelets", ZThK 58, 1961, p.6 の所説を von Rad, G. : Weisheit in Israel, Neukirchen: Neukirchener Verlag, 1970, p.182 から孫引。

(1974. 3. 31)

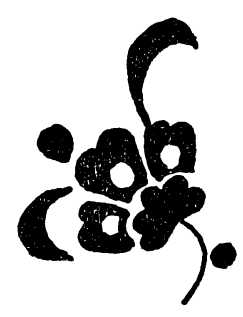




\section{The Semantic Structure of Some Biblical Hebrew Verbs denoting Mental Activity}

\section{Isaku Matsuda}

I intend to analyse the semantic relation of seven Biblical Hebrew verbs which belong to a semantic field of mental activity, ' $h b, s=$ ', $r s \underline{h}, h \not s, r h m$ (pi), h.hn, h.ml, considering their semantic features, or the conditions that permit the use of these verbs semantically. The main results are as follows.

1) ' $h b$ and 's $n$ ' signify the mental activities of man, while $r h \mathrm{~m}$ and $h n n$ denote that of God; the other verbs can take either man or God as the subject.

2) $r h m$ and $h n n$ take exclusively man as their object, whereas $h \not s, r s \underline{h}$ and $h m l$ can take other objects also; particularly $h p s ̣$ governs some ethical terms, $h \mathrm{ml}$ governs animal or some concrete things.

3) The verbs other than ' $h b$ and 's $n$ ' relate the mental activities of man or God to his subordinate.

4) As for $r s ̦ h$ there seems to be a premise that its object does something active to its subject; but the other verbs can be used only if their object exists, with or without the mention of its attribute.

5) On the other hand, the mental activities denoted by the verbs except $r s ̦ h$ do not remain psychic, but intend to bring about some concrete result on the part of their objects.

6) The semantic relation of ' $h b$ and 's $n$ ' is not 'antonymous', but 'complementary'; that is, in Biblical Hebrew "not to love" means "to hate". 